\title{
Areas of Adhesion between Wall and Membrane of Escherichia coli
}

\author{
By M. E. BAYER \\ The Institute for Cancer Research, Philadelphia, \\ Pennsylvania, U.S.A. I9I I I
}

(Accepted for publication 7 May 1968)

\begin{abstract}
SUMMARY
The envelope of Escherichia coli B exhibited areas at which cell wall and protoplasmic membrane were intimately associated. These areas becamevisible in ultrathin sections after the bacteria had been fixed and embedded in plasmolysed state. At numerous areas the protoplasmic membrane was observed to adhere to the wall, while the protoplast had shrunk. Duct-like extensions of the protoplasmic membrane were thus formed. Two hundred to 400 of these wall membrane associations are found per bacterium of $E$. coli $\mathrm{B}$. In a number of cells the chromosomal material is seen in close proximity or connected to a wall membrane association.
\end{abstract}

\section{INTRODUCTION}

The bacterial surface exhibits an array of very different functions: it is responsible for the priming of wall synthesis, it plays an essential part in the execution of cell division, it provides for most of the cell's mechanical stability, as well as for pathways for metabolic products and excretion of toxins, and for exhibiting specific antigens and receptor sites to which bacteriophages adsorb. To understand these various functions a structural definition of the cell surface becomes necessary. It had been shown by Weibull (1958) and McQuillen (1960) that the envelope of Gram-positive bacteria consisted of a rather amorphous outer structure which is generally referred to as 'wall' and an underlying plasma membrane. The analogue building principle, i.e. a wall and a membrane underneath, has been found in Gram-negative bacteria; however, in this group an apparent multilayering of the wall components had been demonstrated by Kellenberger \& Ryter (1958) and others. The layered nature of the outer portion of the wall of Escherichia coli had been established using chemical and morphological techniques by Weidel, Frank \& Martin (1960), and for other Gramnegative bacteria by Murray (I962). Underneath these layered components a rigid wall layer of a glycosaminopeptide had been found, together with a proteinaceous particulate substance (Martin \& Frank, I962). The glycosaminopeptide is largely responsible for the rigidity of the cell wall and also for priming of mucopolymer synthesis, whereas the outer layers of the wall containing lipoprotein and lipopolysccharide exhibit the antigenic and endotoxic activities (Weidel \& Primosigh, 1958; Salton, 1960). The study of these wall lipopolysaccharides has led to the immunological classification of bacterial strains (Westphal, Kauffman, Lüderitz \& Stierlin, 1960). In addition to the presence of antigenic sites, one has also to postulate that the bacteriophage receptors have to be localized on the wall exposed to the cell's environment. 
The presence of a separate membrane with selective permeability underneath the rigid wall had been demonstrated with the light microscope as early as 1903 by Fischer, who described the phenomenon of plasmolysis which consists of a shrinkage of the protoplast due to loss of water inside the cage-like wall. Plasmolysis and prevention of bursting of the protoplast by sucrose has been applied in numerous studies on membrane permeability, measurement of protoplasmic turgor and of incorporation of metabolites (see Britten, 1965), as well as in investigations on cell division (Cota-Robles, I963) and spheroplast formation (Weibull, 1953). These investigations seemed to indicate that wall and membrane can be more or less completely separated, functionally and structurally (Salton, I967).

We have found that in plasmolysed $E$. coli the separation of wall and membrane is incomplete. There exist numerous sites of the cell envelope at which the protoplasmic membrane stays intimately associated with the wall. The fine structure of these wallmembrane associations is described in the present report.

\section{METHODS}

Escherichia coli strain B was grown logarithmically in $\mathrm{I}$ o ml. nutrient broth (I \% Bacto-tryptone, $0.5 \%$ yeast extract, $0.5 \% \mathrm{NaCl}, 0 . \mathrm{I} \%$ glucose, adjusted to $\mathrm{pH} 7$ with $\mathrm{N}-\mathrm{NaOH}$ ) at $37^{\circ}$ with aeration (about $200 \mathrm{ml}$. air $/ \mathrm{min}$.), with a generation time of 25 to $30 \mathrm{~min}$. until counts between $5 \times 10^{7} / \mathrm{ml}$. and $2 \times 10^{8} / \mathrm{ml}$. were reached. The bacteria were then plasmolysed by adding equal volumes of nutrient medium ( $\mathrm{pH} 6.8$ to $7 \cdot 0$ ) containing 20 or $40 \%(\mathrm{w} / \mathrm{v})$ sucrose and kept for about $2 \mathrm{~min}$. at $37^{\circ}$ with aeration. The bacteria plasmolysed almost immediately in the hypertonic environment (Bayer, 1967b).

The number of organisms per colony grown on nutrient agar was determined by punching-out a colony and suspending the agar piece with the bacteria in nutrient broth. The suspension was then plated on nutrient agar for colony counts. A KlettSummerson photometer was used for turbidimetric measurements. Besides colony counts bacteria were also counted in a Neubauer chamber with a Zeiss phase-contrast microscope. For electron-microscopic studies the plasmolysed bacteria were fixed by mixing the suspension with an equal volume of the following fixative: I part $32 \%$ $(\mathrm{w} / \mathrm{v})$ formaldehyde solution made out of paraformaldehyde dissolved in water +1 part nutrient medium containing $20 \%$ or $40 \%$ sucrose; shortly before fixation the solution was adjusted to $\mathrm{pH}_{7}$ by adding $\mathrm{N}-\mathrm{NaOH}$. Thus the final fixing solutions contain 10 or $20 \%(\mathrm{w} / \mathrm{v})$ sucrose. Fixation was done at a temperature between $18^{\circ}$ and $20^{\circ}$ in centrifuge tubes. After $2 \mathrm{hr}$ the bacteria were centrifuged at $7000 \mathrm{~g}$ for $15 \mathrm{~min}$. in the angle head of a Sorvall centrifuge. The pellet was gently resuspended in $\mathrm{I} \%(\mathrm{w} / \mathrm{v})$ osmium tetraoxide solution to which sucrose, to a final concentration of $10 \%$ or $20 \%$, had been added shortly before fixation, and adjusted to $\mathrm{pH} 7$ with $\mathrm{N}-\mathrm{NaOH}$ or with Michaelis buffer. The $\mathrm{OsO}_{4}$ fixation lasted for $\mathrm{I}$ hr at a temperature of $18^{\circ}$ to $20^{\circ}$. The suspensions were then centrifuged at $4000 \mathrm{~g}$ for $\mathrm{IO} \mathrm{min}$. and the pellet was resuspended in an aqueous solution containing: $0.5 \% \mathrm{OsO}_{4}+0.5 \%$ freshly prepared uranyl acetate and $10 \%$ or $20 \%$ sucrose. The preparations were left in this fixative overnight at a temperature of $18^{\circ}$ to $20^{\circ}$. After stepwise dehydration in acetone the material was collected in pellets and embedded in Vestopal W (Jaeger, Zurich, Switzerland); grey to silver-grey sections were cut with a diamond knife in a Porter-Blum ultramicrotome equipped with an additional thermal advance or in an 
LKB ultramicrotome. The sections were stained in saturated uranyl acetate solutions for I to $2 \mathrm{~min}$. and stained further with lead hydroxide stain (Reynolds, 1963) for I to $2 \mathrm{~min}$. in a $\mathrm{CO}_{2}$-free atmosphere. The sections were studied and micrographs were taken on Ilford Special Lantern Contrasty plates, usually at a magnification of 40,000 in a Siemens Elmiskop I, equipped with double condenser and pointed filament. The instrument's magnification was calibrated with a cross-grating of 2160 lines $/ \mathrm{mm}$.

\section{RESULTS}

\section{Viability of the bacteria in sucrose}

When Escherichia coli в was assayed on $10 \%$ or $20 \%$ sucrose plates the same number of colonies developed after $\mathrm{I} 2 \mathrm{hr}$ as on control plates without sucrose. However, the size of the colonies decreased in $10 \%$ sucrose to about one half of the size of the control colonies, whereas in $20 \%$ sucrose the colonies were frequently as small as pinpoints and increased in size after 24 to $48 \mathrm{hr}$ of incubation. After 2-3 days of incubation, all the colonies on the plates containing $20 \%$ sucrose had reached the size of the control colonies which had been grown for $\mathrm{I} 2 \mathrm{hr}$ without sucrose. The number of bacteria per colony of about $3 \mathrm{~mm}$. diameter on nutrient agar plates with or without sucrose was about 5 to $6 \times 10^{8}$, which indicates that there was the same number of bacteria to be expected per equally sized colony. The effect of sucrose on the colony size can be attributed mainly to a decrease in the speed of growth. In liquid cultures aerated in test-tubes the results support this assumption. The generation time in nutrient broth at $37^{\circ}$ was about $30 \mathrm{~min}$. In $10 \%$ sucrose this time was only slightly increased to about $35 \mathrm{~min}$., whereas in $20 \%$ sucrose the generation time rose to $68 \mathrm{~min}$, For estimation of the number of bacteria by turbimetry, a calibration curve for each of the sucrose concentrations had to be made since the turbidities of the bacterial suspensions decrease with increasing concentrations of sucrose. For example: a turbimetric value corresponding to $10^{8}$ bacteria/ml. nutrient medium corresponded to $2 \times 10^{8}$ bacteria $/ \mathrm{ml}$. nutrient medium containing $10 \%$ sucrose and to $4 \times 10^{8} / \mathrm{ml}$. nutrient medium containing $20 \%$ sucrose. The concentration of bacteria was also determined by colony counts and by microscopic counts. The dimensions (length and width) of the bacteria growing in sucrose were smaller, but also rather long forms-up to $30 \mu$-became visible in the microscope, especially after growth in $20 \%$ sucrose.

\section{Light microscopy}

When the logarithmically growing bacteria were suddenly exposed to sucrose in concentrations of $10 \%$ or $20 \%$, one observed in the phase-contrast microscope that in most of the bacteria the protoplast shrank almost immediately and that these forms stayed plasmolysed for about $8 \mathrm{~min}$. At the end of this period the protoplasts began to swell until after ro min. in $10 \%$ sucrose most of the forms had filled the entire visible space inside the rigid cell wall. In $20 \%$ sucrose the organisms required considerably more time for re-establishment of their former protoplasmic volume. In addition, a greater variation in the speed of recovery between individual organisms of a culture became obvious; some organisms recovered morphologically after only 8 to $10 \mathrm{~min}$. whereas others needed 15 min. or longer. A few (around $2 \%$ ) organisms did not seem to plasmolyse at all. 


\section{Electron microscopy}

In ultrathin sections of bacteria which had been plasmolysed in sucrose the staining with uranyl acetate and lead acetate was extraordinarily difficult. Precipitates frequently developed over the area of some of the bacteria but also the background which contained no bacteria seemed to be stained and often showed a considerable increase in granularity (e.g. Pl. I, fig. I). Variation of staining time and concentration of the staining solution did not significantly change this tendency for precipitation.

Escherichia coli, after embedding and thin sectioning, exhibits clearly the structural elements of the wall and the protoplast typical of a Gram-negative organism. The wall consists of a pair of contrasty layers which are separated by a less dense layer; sometimes an extra dense layer becomes visible as a separate line inside the inner dense layers (Pl. I, fig. I); this profile has been described in recent years by a number of investigators (Kellenberger \& Ryter, 1958; Glauert, I962; Murray, I968; DePetris, 1967).

The appearance of the wall in cross-sections seems unaltered when the bacteria were exposed to hypertonic sucrose solutions (P1. I, fig. 2; Pl. 2, fig. 3). The inner contour of the wall, especially its granular-globular portion, became more distinct since the protoplasmic membrane had retracted from the wall. The thickness of such a portion of the wall measured about $160 \AA$. In those areas where for a short distance no globular layer was detectable, the thickness of the structure was reduced to about $95 \AA$.

Brief exposure of the bacterium to hypertonic medium causes the protoplast to become dehydrated and shrink. A separation of the protoplast from the rigid wall's inner layer then became visible (Pl. I, fig. I, 2). However, in about $2 \%$ of the bacteria a separation of wall and membrane was observed in the light microscope, even in $20 \%$ sucrose solutions; a portion of such a bacterium is visible at top left (P1. I, fig. I). In the plasmolysed bacteria the space between wall and shrunken protoplast appeared to be 'empty', with the exception that a number of protoplasmic extensions or 'ducts' showed up which maintained a connexion between wall and membrane. (The reason for our terminology is given in the Discussion.) At these areas of the wall the protoplasmic membrane was locally held back, while the main portion of the protoplast had shrunk; thus bridges or 'ducts' were formed which maintained a connexion between the protoplast and localized areas at the inside of the wall (Pl. I, fig. I, 2; Pl. 2, fig. 5).

In a plasmolysed bacterium the contour of the cell surface in an area of intimate contact between wall and membrane was sometimes straight but more frequently it was incurved (Pl. I, fig. I, 2; Pl. 2, fig. 4). The contour of the protoplasmic membrane might not change its direction at an area of wall membrane contact (Pl. 2, fig. 4) or, as in most cases, the membrane might be pulled out to a more or less elongated duct (Pl. I, fig. I, 2; Pl. 2, fig. 5) The ducted type in combination with a concave area of wall was most frequently observed: of 178 wall membrane associations counted on randomly picked bacteria, I I5 (65\%) were of this type, whereas in 54 cases $(30 \%)$ the membrane formed a duct without visibly indenting the wall. At the deepest point of such an indentation, as well as at other types of wall membrane associations, the wall sometimes seemed to lack the granular layer.

The outer contour of the protoplast was represented by the triple-layered structure of the protoplasmic membrane (Pl. I, fig. I, 2; Pl. 4, fig. 9) about $90 \AA$ in thickness. However, very often it was impossible to delineate the contour of the inner layer facing 
the protoplasm because the electron densities of the fixed protoplasmic contents and the inner layer of the protoplasmic membrane were about equal (Pl. I, fig. 2). Occasionally the protoplasmic membrane appeared to be granular or beaded. The contour of the protoplasmic membrane was continuous with the membrane contour of a duct. At the areas where a duct terminated at the wall's inner surface, the structural definition of the membrane was, in general, blurred and estimations of the thickness of the layers involved were difficult to obtain. This difficulty might be caused by an inevitable oblique-sectioning of the wavy contact area which is of smaller dimensions than the thickness of a section. In the few cases where

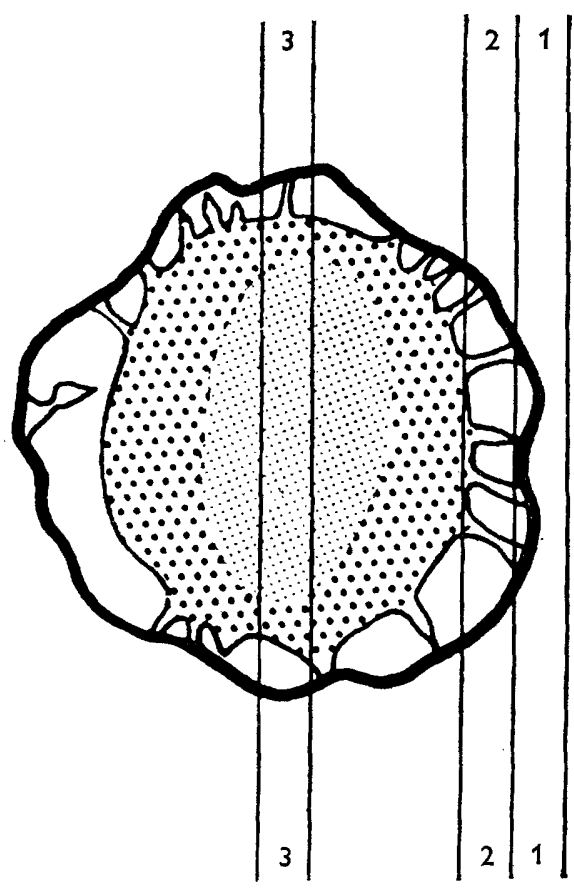

Fig. I

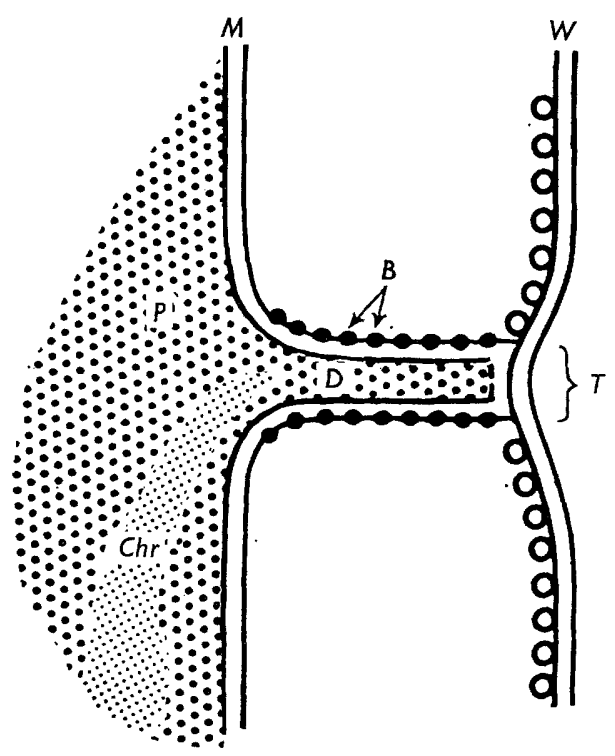

Fig. 2

Fig. I. Diagram of various section planes through a plasmolysed cell.

Fig. 2. Schematic diagram of a wall membrane association as seen after plasmolysis. $P=$ protoplast, $\boldsymbol{M}=$ protoplasmic membrane, $\boldsymbol{B}=$ 'beads' on protoplasmic membrane, $D=$ protoplasmic duct, $T=$ termination area of duct, $W=$ wall (the circles attached to the inner 'layer' of the wall symbolize the particulate protein of the rigid layer), $\mathrm{Chr}=$ chromososome.

measurements were possible the wall showed a thickness between $95 \AA$ (without its granular portion) and $160 \AA$ (when the granular layer of the wall was visible). The over-all thickness of the wall membrane complex, when definable, measured 200 to $250 \AA$; its diameters varied from $220 \AA$ to occasionally over $500 \AA$. The wall membrane complex can be defined as a zone where membrane and wall are so closely associated that even after plasmolysis no free space is apparent between the structures.

For a better orientation with respect to the section planes in question, a diagram of a cross-section through a plasmolysed cell is shown in Fig. I, which relates roughly to Fig. 2. The assembly of the various elements of a duct in such a cross-section through 
the wall, section plane 3 , Fig. I, i.e. in a section parallel to the long axis of a duct, is shown in Fig. 2 and can be observed in Pl. I, fig. I, 2 and Pl. 2, fig. 5.

If sections more or less tangential to the surface included the outermost surface of the wall (section plane I, Fig. I), the following structures were encountered: facing the environment the wall had a weakly defined contour; it seemed to fade out into the surrounding medium (P1. 3, fig. 6b). There the material consisted of a fine granular and sponge-like substance. In sections along the surface one frequently observed circular areas which were scattered over the entire area of the wall ( $\mathrm{T}$ in Pl. 3, fig. $6 b$ ); they are considered to represent the termination areas of the protoplasmic ducts, possibly including short portions of ducts. Their diameters measured 230 to $270 \AA$. In addition, there were other structures visible in these sections: occasionally wall extrusions ( $L$ in Pl. 3, fig. 6 and 7) were seen as well-defined circular or elliptical elements 150 to $200 \AA$ in diameter ( $\mathrm{L}$ in Pl. 3, fig. 6) which may be regarded as sections of wall lipid which is normally found on the surface of Escherichia coli (Bayer \& Anderson, I965; DePetris, 1967). In sections along the cell surface channel-like structures were occasionally observed in the wall ( $C h$ in Pl. 3, fig. 6). They measured 85 to $90 \AA$ across.

When the area between wall and shrunken protoplast was sectioned (section plane 2, Fig. I) the only structures visible were cross-sections of the connecting protoplasmic ducts. In general the cross-sections of these ducts appeared to be more or less circular in shape (Pl. 3, fig. 7). The ducts measured 200 to $350 \AA$ across, usually 240 to $280 \AA$, and were composed of the triple-layered membrane of a thickness about $90 \AA$ (Pl. 2, fig. 5), which agrees with the dimensions of the protoplasmic membrane at other locations of the protoplast. The tubelike structure of a duct showed a central core of a diameter $40 \AA$ or more (Pl. 2, fig. 5, left duct) which seemed frequently to be 'plugged' with material (Pl. 3, fig. 7, white arrows), sometimes with a dark dot in the centre (P1. 3, fig. 7, insert). The length of a duct depended on the extent of plasmolysis and also on the local contour of the wall. The membranes in the ducts often exhibited a beaded structure, in which the 'beads' are shown in higher contrast (P1. 3, fig. 7, insert) with a diameter of 25 to $30 \AA$.

Lengitudinal sections and serial sections showed that the distribution of the connecting ducts over the entire bacterium seemed to be random (Pl. I, fig. I, 2; Pl. 3, fig. 7). At the poles of the bacteria the ducts were often longer than at other areas. If one assumes the length of the bacterium to be $\mathrm{I} \cdot 5$ to $2 \mu$ and the section thickness to range between $600 \AA$ for grey-coloured sections and $800 \AA$ for silver-coloured sections (Peachy, 1958; Bachmann \& Sitte, 1958), the total number of the wall-membrane connexions per bacterium can be estimated as 200 to 400 .

The protoplasmic contents were condensed after plasmolysis as compared to normal growth conditions. The ribosomes were closely packed and the space between them appeared to be much denser than comparable areas of control bacteria. Thus, the contrast variation in the protoplasm was decreased (P1. I, figs. I, 2; P1. 4, fig. 8). The fibrous chromosomal apparatus became clearly visible against this dense protoplasm. Often portions or strands of 'light' material appeared to extend from the chromosome through the dense protoplasmic contents and to aim at some of the areas of wall membrane associations (P1. I, fig. I; P1. 4, fig. 8). In sets of serial sections through I 2 cells of different preparations it was observed that the chromosome membrane 'contact' occurred at more than one site per cell ( $\mathrm{Pl} .4$, fig. 9). 


\section{DISCUSSION}

Under osmotic conditions normally present in cultures, cell wall and protoplasmic membrane of Escherichia coli B are found in more or less close contact; this applies also for strain C I (Bayer, unpublished). Presumably, the membrane is forced against the mechanically rigid wall by the turgor of the protoplast, the pressure of which has been determined by Mitchell \& Moyle (I956) and by McQuillen (1960) to be 3 to $5 \mathrm{~kg}$./ $\mathrm{cm} .{ }^{2}$. Only occasionally does one find areas where a slight separation of protoplast and wall becomes visible and there one might be able to observe areas where wall and membrane adhere to one another. However, these areas become conspicuous after osmotic shrinkage of the protoplast. Similar structures have previously been described as protoplasmic extensions by Cota-Robles (1963) and Birdsell \& CotaRobels (1967) in connexion with investigations on cell divisions and lysis of $E$. coli. Connexions or 'bridges' between membrane and wall have also been reported for a number of other micro-organisms like streptomyces (Glauert \& Hopwood, 1960), Bacillus subtilis (Glauert et al. 1961) and Listeria (Edwards \& Stevens, I963). Since the cells have not been plasmolysed, a comparison of their bridge-like structures and the 'ducts' of our report becomes difficult. In preparations of $E$. coli the wall frequently exhibits funnel-like invaginations at the sites of wall membrane attachment (Pl. I, fig. I; Pl. 2, fig. 5); these structures can be interpreted as being caused by the pulling forces to which the connexions are subjected while the protoplast retracts. They might correspond to the 'dimpled holes' seen in cell walls prepared by the criticalpoint method (Anderson \& Oster, 1954).

The beaded appearance of the protoplasmic membrane in some areas could very well represent an alignment of membrane constituents similar to those described by Sjöstrand (1963). However, such an interpretation should be regarded as tentative until more evidence for the existence of the micellar arrangement of the protoplasmic membrane is available (Robertson, 1966).

The areas of wall membrane contact might be related to the centres of wall synthesis which have been shown to be about equally numerous and also randomly distributed over the entire wall of Escherichia coli (Bayer, 1967a). One might, tentatively, assume that the areas of wall membrane contact represent mechanically weak areas of the wall at which the cells can be injured by osmotic shock (Bayer, $1967 b$ ). It has been shown that a light osmotic shock releases a number of enzymes and nucleotides (Heppel, 1967) and amino acid binding proteins (Piperno \& Oxender, 1966), suggesting that these substances are membrane-bound or located near the surface of the organism. The reports of Anraku (I966) and Fox, Carter \& Kennedy (1967), on reduction of galactose transfer systems after osmotic shock, would permit the same conclusion. The intimate junction of wall and membrane at these areas would also account for the apparent difficulties in preparing 'pure' wall preparations or 'pure' membranes (Salton, 1967).

It has been demonstrated that the bacteriophages $\mathrm{T}$ I to $\mathrm{T} 7$ adsorb almost exclusively to those areas of the wall which show an association between wall and membrane (Bayer, I968). The transport of the injected nucleic acids is likely to occur through the protoplasmic 'ducts'. Because of this we prefer the term 'duct' to that of 'extension' or 'bridge'.

The presence of connexions of the protoplasmic ducts to the cell's chromosomal 
apparatus is suggested by pictures like Pl. 4, fig. 8, 9. Such an arrangement would resemble observations of Jacob, Ryter \& Cuzin (1966), who suggested an anchoring of the chromosome at the membrane or its derivatives in Bacillus subtilis. Ryter \& Jacob (1966) and Ryter (I968) have also shown that the nuclear material comes in close contact with the membrane of Escherichia coli. Application of plasmolysis makes it easily possible to discern structurally the contact areas of chromosome and membrane from the residual portions of the cell envelope. Much more material has to be investigated before one can decide whether all the chromosomal contacts with the membrane occur at a wall-membrane association. One might derive from a number of our micrographs that there seem to exist more than one zone in $E$. coli at which the chromosomal apparatus comes in close proximity to a wall-membrane association. Since these cells are growing rapidly and therefore contain a multiple chromosome set, the suggested value of one anchoring area per cell (Ryter, 1968) might still be applicable. However, these observations have to be backed by cytochemical and biochemical work before firm conclusions can be drawn.

I wish to thank Drs T. F. Anderson, D. Brown and G. T. Rudkin for valuable suggestions in preparing the manuscript and Mrs C. Gross for her technical assistance. This work was supported by National Science Foundation U.S.A. grant GB-4640, Public Health Service Research grants CA 06927 and I SOI FR 05539 from the National Institutes of Health, and an appropriation from the Commonwealth of Pennsylvania.

\section{REFERENCES}

ANDERSON, T. F. \& OsTer, C. F. (I954). An electron microscope study of the digestion of $E$. coli by trypsin and lysozyme. Proc. 3 rd int. Conf. Electron Microsc., London.

ANRAKU, Y. (1966). The reduction and restoration of galactose transport in osmotically shocked cells of Escherichia coli. J. biol. Chem. 252, 793.

Bachmann, A. \& SitTe, P. (1958). Über Schnittdickenbestimmung nach dem Tolanski-Verfahren. Proc. 4th Int. Conf. Electron Microsc., Berlin.

BAYER, M.E. (1967a). The cell wall of Escherichia coli: Early effects of penicillin treatment and deprivation of diaminopimelic acid. J. gen. Microbiol. 46, 237.

BAYER, M. E. $(1967 b)$. Response of cell walls of Escherichia coli to a sudden reduction of the environmental osmotic pressure. J. Bact. $\mathbf{9 3}$, I I04.

BAYER, M. E. (1968). The adsorption of bacteriophages to adhesions between wall and membrane of Escherichia coli. J. Virology 2, 346.

Bayer, M. E. \& ANDerson, T. F. (1965). The surface structure of Escherichia coli. Proc. natn. Acad. Sci. U.S.A. 54, 1592.

Birdsell, D. C. \& Cota-Robles, E. H. (1967). Production and ultrastructure of lysozyme and ethylenediaminetetraacetate-lysozyme spheroplasts of Escherichia coli. J. Bact. 93, 427.

BRITten, R. J. (1965). Concentration of small molecules within the bacterial cell. Symp. Soc. gen. Microbiol. 15, 57.

Cota-RoвLes, E. H. (1963). Electron microscopy of plasmolysis in Escherichia coli. J. Bact. 85, 499.

DePeTRIs, S. (1967). Ultrastructure of the cell wall of Escherichia coli and the chemical nature of its constituent layers. J. ultrastruct. Res. $\mathbf{9 9}, 45$.

EdWARds, M. \& Stevens, R. W. (1963). Fine structure of Listeria monocytogenes. J. Bact. 86, 414.

FISCHER, A. (1903). Vorlesungen über Bakterien. Jena: Fischer Verlag.

Fox, F., CarTer, J. R. \& KenNedy, E. P. (1967). Genetic control of the membrane protein component of the lactose transport system of Escherichia coli. Proc. natn. Acad. Sci.. U.S.A. 57, 698.

GlaUert, A. M. (1962). Fine structure of bacteria. Br. med. Bull. $\mathbf{1 8 , 2 4 5 .}$ 
GlauerT, A. \& Hopwood, D. A. (1960). The fine structure of Streptomyces coelicolor. I. The cytoplasmic membrane system. J. biophys. biochem. Cytol. 7, 479.

Glauert, A., Brieger, E. M. \& Allen, J. M. (196I). The fine structure of vegetative cells of Bacillus subtilis. Expl Cell Res. 22, 73.

HePpeL, L. A. (1967). Selective release of enzymes from bacteria. Science, N.Y. 156, I45I.

JACOB, F., RYTER, A. \& CUZIN, F. (1966). On the association between DNA and membrane in bacteria. Proc. R. Soc. B x64, 267.

Kellenberger, E. A. \& Ryter, A. (1958). Cell wall and cytoplasmic membrane of Escherichia coli. J. biochem. biophys. Cytol. 4, 323.

Kozloff, L. M. \& Henderson, K. (1955). Action of complexes of the zinc group metals on the tail protein of bacteriophage $\mathrm{T} 2 \mathrm{r}^{+}$. Nature, Lond. $\mathbf{1 7 6}$, 1169.

Martin, H. H. \& Frank, H. (I962). Quantitative Bausteinalayse der Stützmembran in der Zellwand von Escherichia coli в. Z. Naturf. 17b, 190.

MCQuillen, K. (1960). In The Bacteria. Ed. by I. C. Gunsalus and R. Y. Stanier, vol. I, p. 249. New York: Academic Press.

Mitchell, P. \& MoYle, J. (1956). Osmotic function and structure in bacteria. Symp. Soc. gen. Microbiol. 6, 150.

MurRay, R. G. E. (1962). Fine structure and taxonomy of bacteria. Symp. Soc. gen. Microbiol. 12 II 9 .

MURRAY, R. G. E. (1968). Bacterial cell wall anatomy in relation to the formation of spheroplasts and protoplasts. In Microbial Protoplasts, Spheroplasts and L-forms. Ed. by L. B. Guze. Baltimore: Williams \& Wilkins Co.

Peachy, L. D. (1958). Thin sections. I. A study of section thickness and physical distortion produced during microtomy. J. biophys. biochem. Cytol. 4, 233.

PIPERNo, J. A. \& OXENDER, D. L. (1966). Amino-acid-binding protein released from Escherichia coli by osmotic shock. J. biol. Chem. 241, 5732 .

ReYNoLDS, E. S. (1963). The use of lead citrate at high $\mathrm{pH}$ as an electron-opaque stain in electron microscopy. J. Cell Biol. r7, 208.

RoBertson, J. D. (1966). Granulo-fibrillar and globular substructure in unit membranes. Ann. N.Y. Acad. Sci. r37, $42 \mathrm{I}$.

RYTER, A. (1968). Association of the nucleus and the membrane of bacteria: a morphological study. Bact. Rev. 32, 39.

RYTER, A. \& JACOB, F. (I966). Étude morphologique de la liaison du noyau a la membrane chez E. coli et chez les protoplastes de B. subtilis. Annls Inst. Pasteur, Paris п Iо, $80 \mathrm{I}$.

Salton, M. R. J. (I960). In The Bacteria. Ed. by I. C. Gunsalus and R. Y. Stanier, vol. I, p. 97. New York: Academic Press.

Salton, M. R. J. (1967). Structure and function of bacterial cell membranes. A. Rev. Microbiol, 2r, 417.

SJöstraND, F. S. (1963). A new ultrastructura element of the membranes in mitochondria and of some cytoplasmic membranes. J. ultrastruct. Res. 9, 340.

Weibull, C. (1953). The isolation of protoplasts from Bacillus megaterium by controlled treatment with lysozyme. J. Bact. 66, 688.

Weibull, C. (1958). Bacterial protoplasts. A. Rev. Microbiol. I2, I.

Weidel, W. \& Primosigh, J. (1958). Biochemical parallels between lysis by virulent phage and lysis by penicillin. J. gen. Microbiol. 18, 513 .

Weidel, W., Frank, H. \& Martin, H. H. (I960). The rigid layer of the cell wall of Escherichia coli strain B. J. gen. Microbiol. 22, 158.

Westrhal, O., Kauffman, F., Lüderitz, O. \& Stierlin, H. (I960). Über die Immunchemie des O-antigens der Enterobakterien. Zentbl. Bakt. Parasitkde. 179, 336. 


\section{EXPLANATION OF PLATES}

\section{Plate I}

Fig. I. Plasmolysed dividing Escherichia coli в in an almost longitudinal section. Portion of an unplasmolysed cell at upper left portion of picture. Note the numerous associations between wall and membrane. The bar represents $1000 \AA$ in this and the following figures. $\times 62,000$.

Fig. 2. Cross-section of $E$. coli B after $2 \mathrm{~min}$. in $20 \%$ sucrose. $\times 140,000$.

\section{Plate 2}

Fig. 3. Typical view of cross-section through the wall of a plasmolysed $E$. coli. The granular layer faces the protoplast which has, in this figure, retracted beyond the area shown. $\times 250,000$.

Fig. 4. Wall contour seems to lack granular layer at zone of contact with membrane. $\times 280,000$.

Fig. 5. Longitudinal and oblique section through 'ducts'. $P=$ Protoplast; $W=$ wall. $\times 280,000$.

\section{Plate 3}

Fig. 6. E. coli wall. Insert (a) shows oblique cut of plasmolysed $E$. coli; the area inside the 'rectangle' represents an almost tangential section which is shown enlarged to $\times 220,000$ in $(b)$. $\mathrm{L}=$ finger-like extrusion of the flexible surface layers; $C h=$ channel-like structures. For further symbols see legend to Fig. 2.

Fig. 7. Plasmolysed cell in tangential section with ducts crossing the space between wall and retracted protoplast. White arrows point to some of the cross-sections of ducts. $L=$ finger-like extrusions of the surface layers. Insert shows a cross-section of a duct with a central 'plug'. $\times 220,000$.

\section{Plate 4}

Fig. 8. Chromosomal area appears to be connected to the areas where ducts originate; $\times 80,000$. Fig. 9. Chromosome in close contact with the cell membrane at two sites; the cell is only slightly plasmolysed. $\times 55,000$. 
Journal of General Microbiology, Vol. 53, No. 3

Plate I

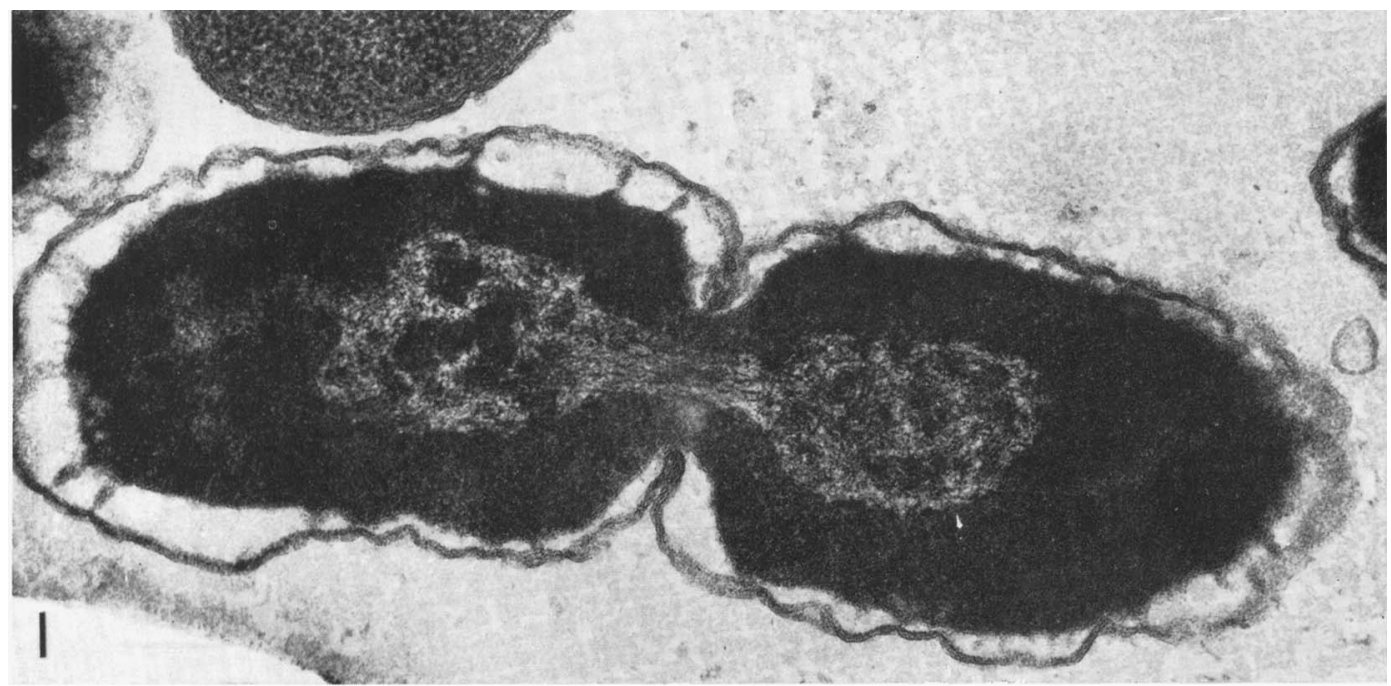

Fig. I

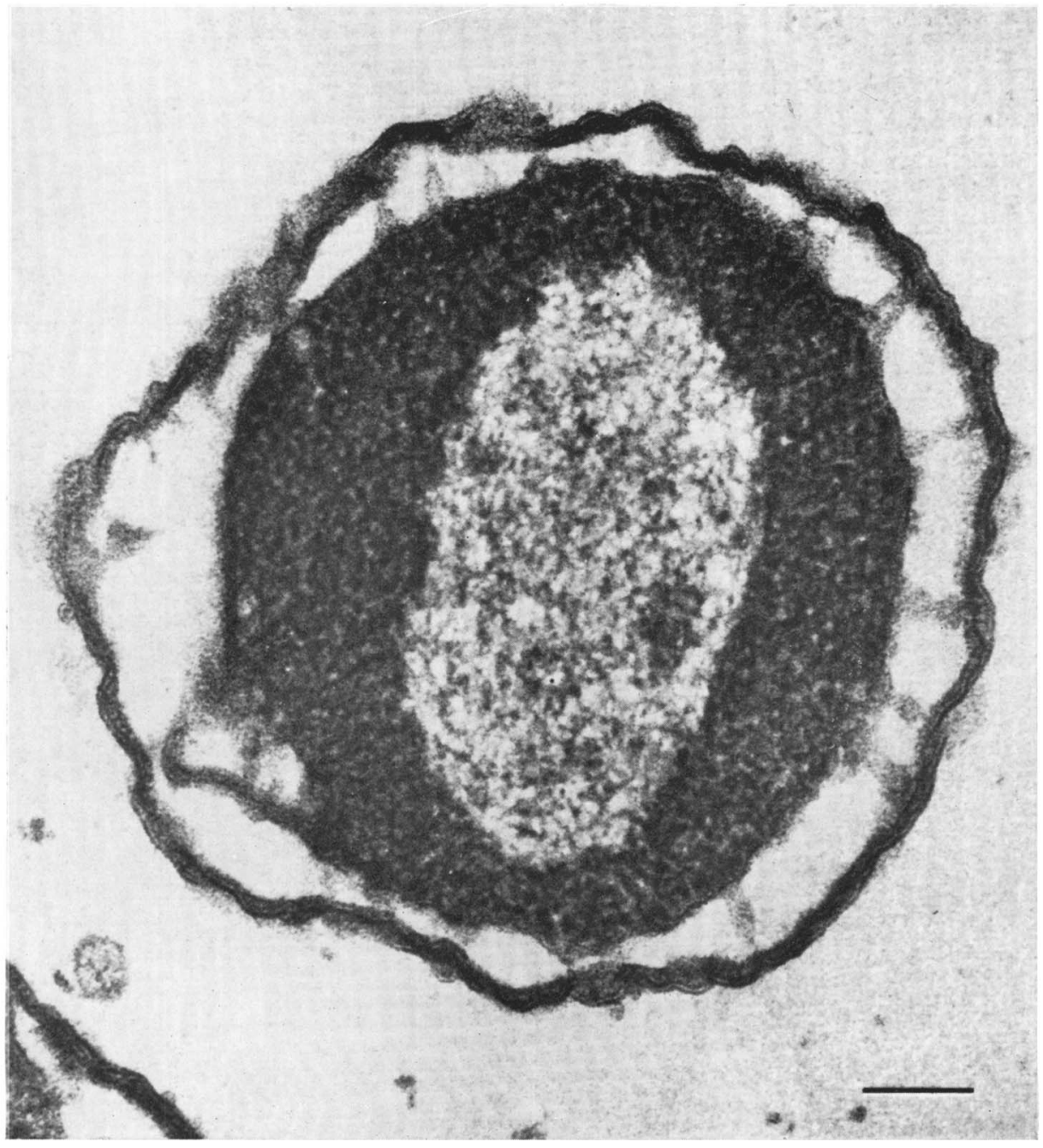

Fig. 2 


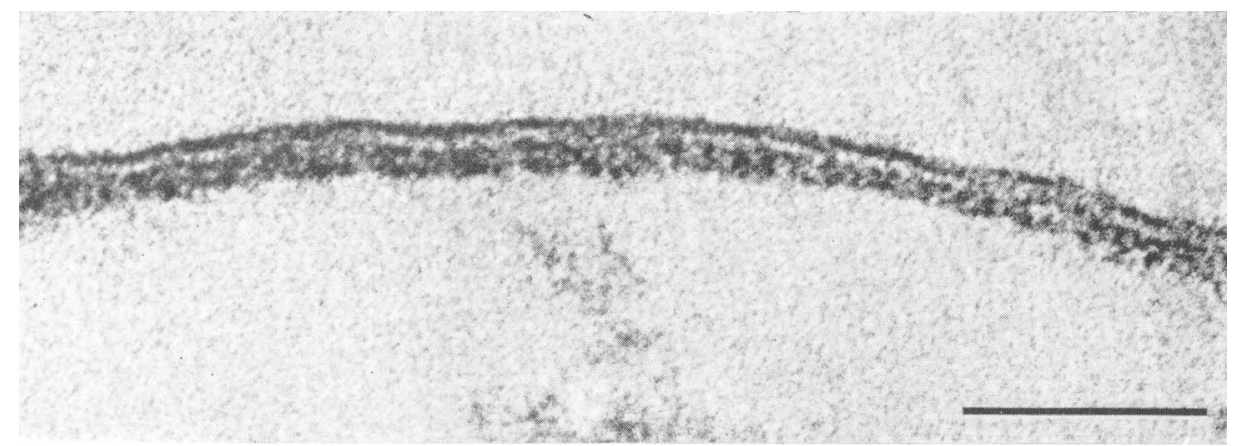

Fig. 3

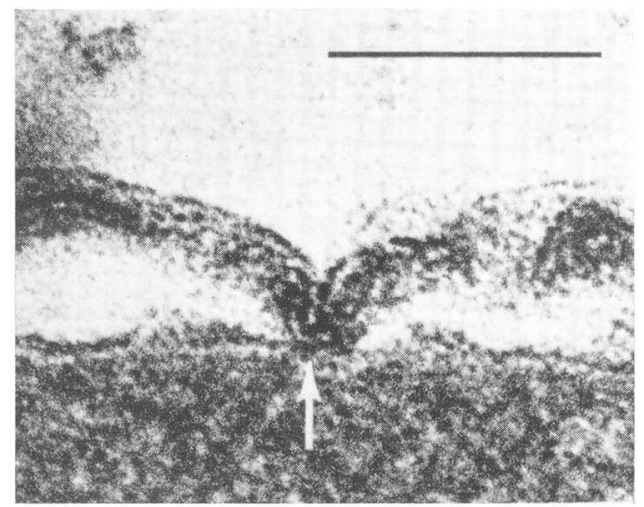

Fig. 4

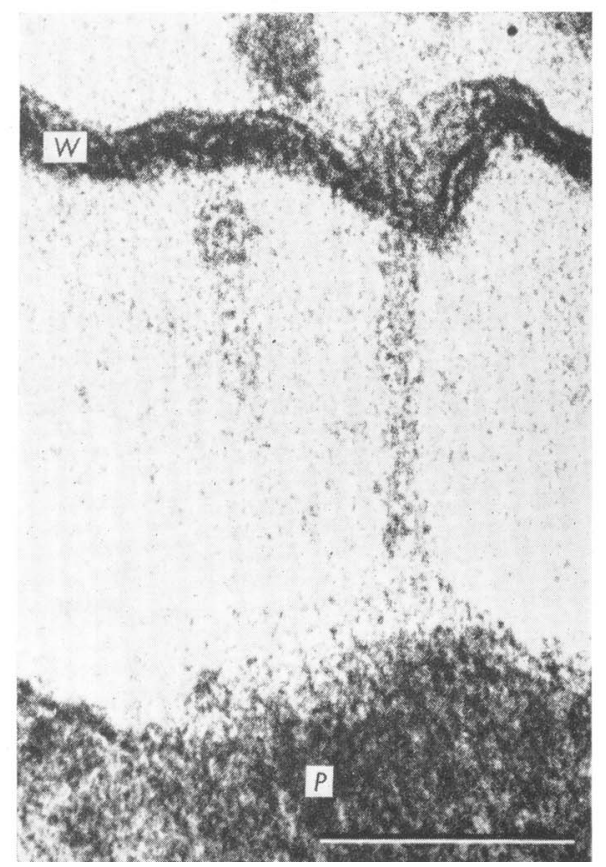

Fig. 5

M. E. BAYER 
Journal of General Microbiology, Vol. 53, No. 3

Plate 3

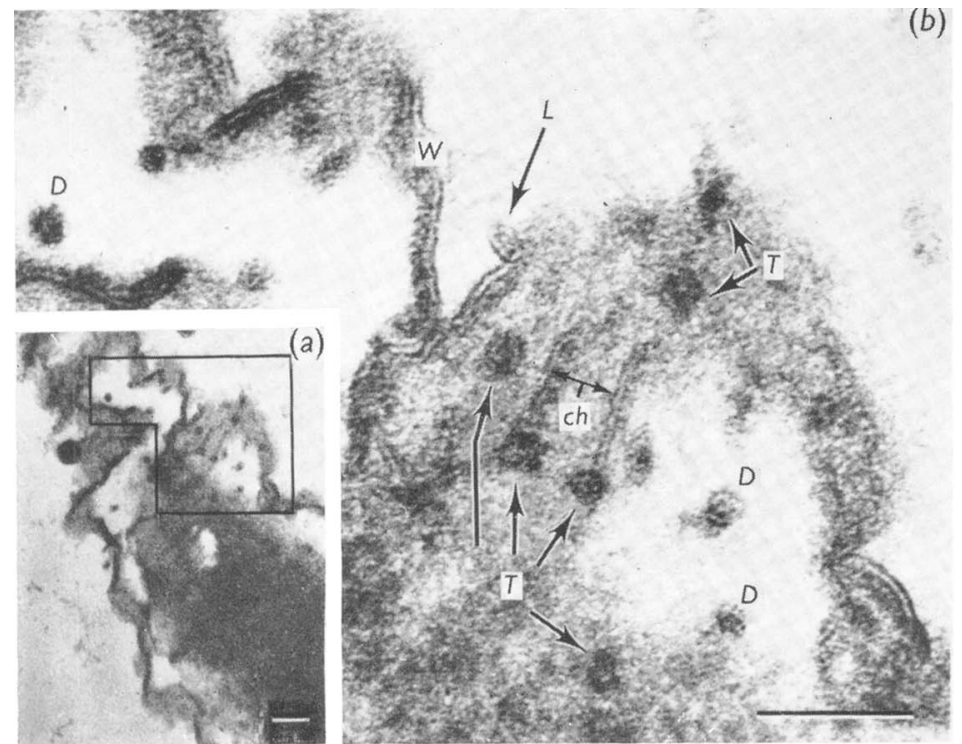

Fig. 6

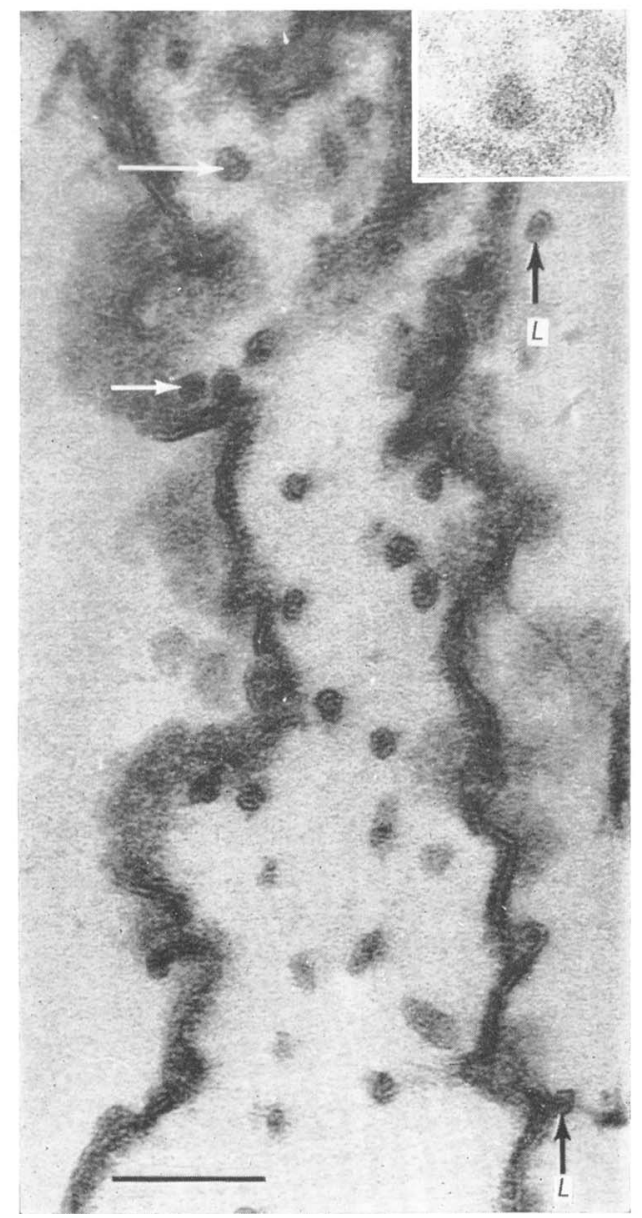

Fig. 7 
Journal of General Microbiology, Vol. 53, No. 3

Plate 4

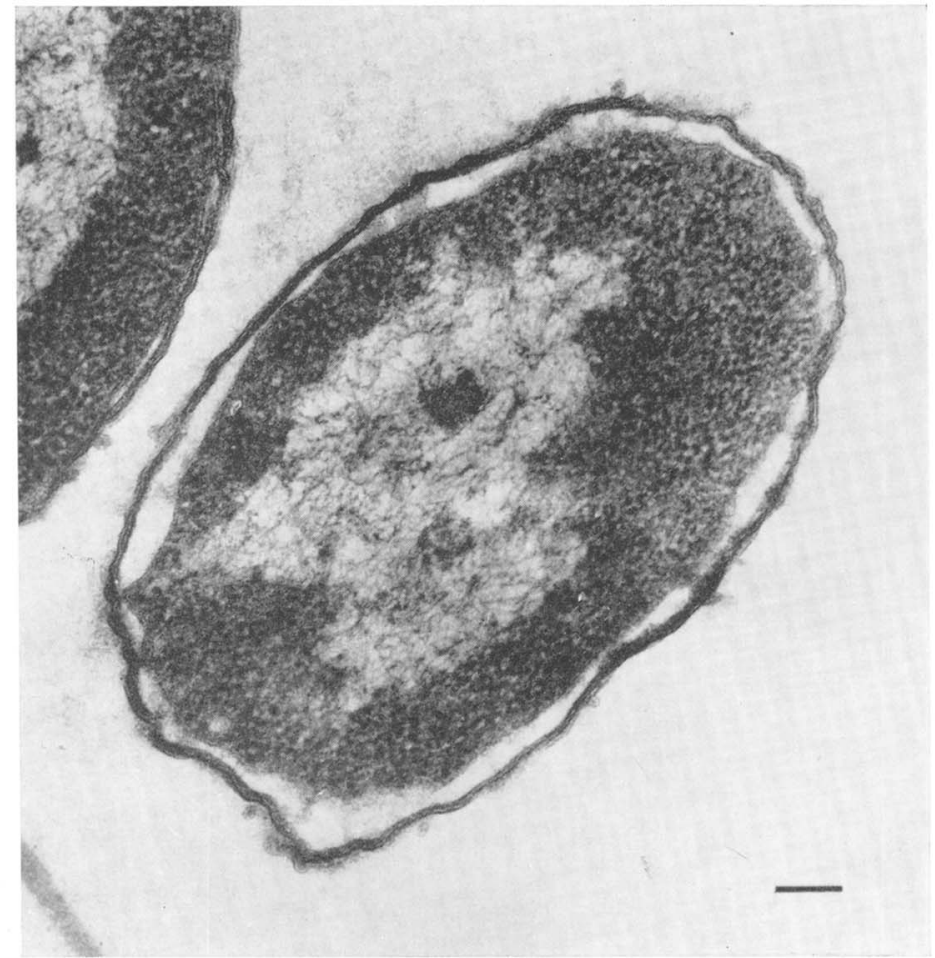

Fig. 8

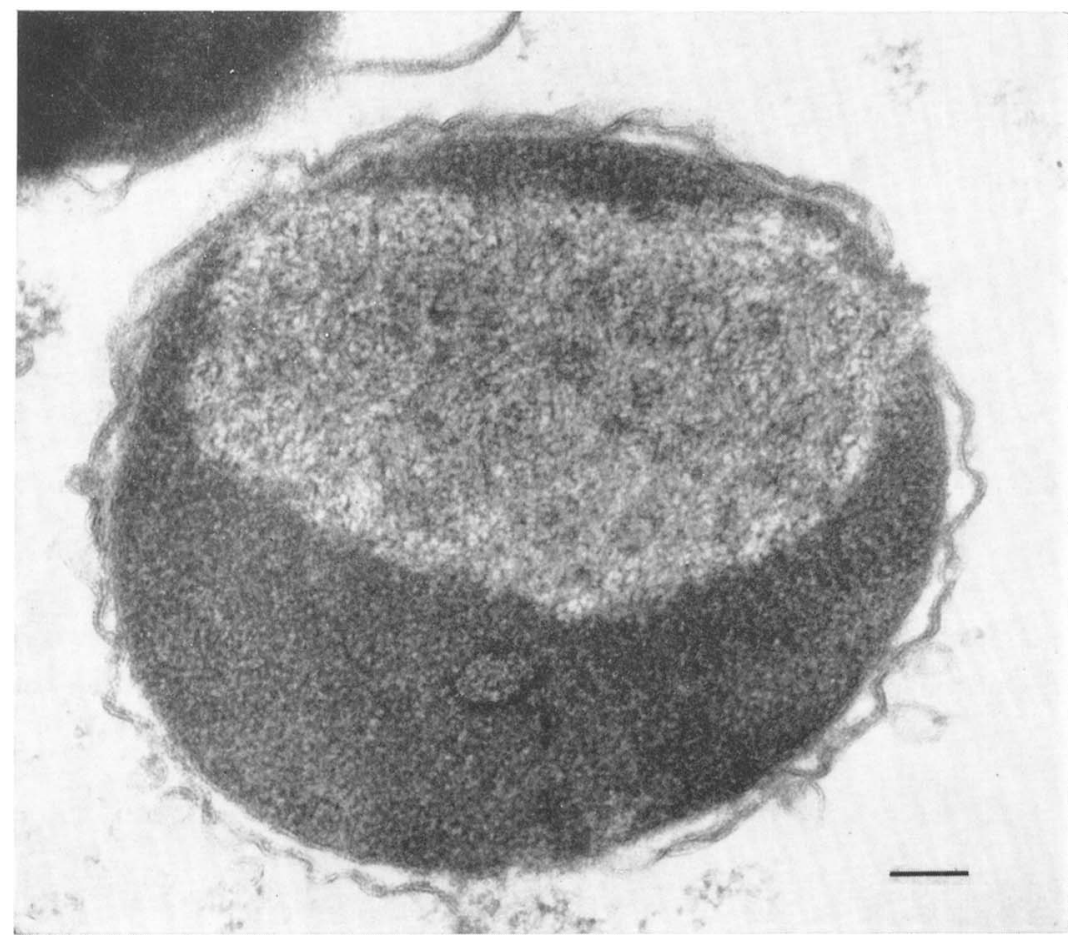

Fig, 9

M. E. BAYER 